\title{
Two Dimensional Modeling to Simulate Stormwater Flows at Photovoltaic Solar Energy Sites
}

\author{
Thomas E. Barnard, ${ }^{1}$ Mohamed Agnaou ${ }^{2}$ and James Barbis ${ }^{1}$ \\ ${ }^{1}$ Amec Foster Wheeler, Blue Bell, Pennsylvania; ${ }^{2}$ Atkins, Tampa, Florida.
}

\begin{abstract}
Solar farms (sometimes known as solar parks or solar fields) are the large scale use of photovoltaic (PV) solar panels to generate green, clean electricity at scale, usually to feed into the grid. Solar farms can cover anything between 1 acre ( 0.40 ha) and several hundred acres (120+ ha), and are usually developed in rural areas. Solar farms consist of arrays of ground mounted rectangular panels that are sloped toward the sun at either fixed or adjustable angles. Amec Foster Wheeler assessed several candidate solar farm sites in Texas for stormwater flooding hazard and designed the stormwater management system for a site in Georgia using two-dimensional (2D) hydrologic and hydraulic $(\mathrm{H} \& \mathrm{H})$ models to simulate the infiltration and overland flow. The FLO-2D software package was used to develop a rectangular grid for runoff calculation. The Soil Conservation Service (SCS) method and the shallow water equations were used to route stormwater runoff across FLO-2D grids. Results were exported to ArcGIS for the creation of maps that displayed maximum velocities and flow depths for different storm events. Input data required for the development of the models was obtained from publicly available sources including U.S. Geological Survey (USGS) 1/3 arc-second digital elevation models (DEM), National Land Cover Database (NLCD), U.S. Department of Agriculture (USDA) soil data and National Hydrography Dataset (NHD) data. These data inputs were supplemented with site field survey data. ESRI ArcGIS software and other tools were used to process the data for the assignment of curve numbers (CN) and ground roughness coefficients (Manning's $n$ value) to the model grid cells. HEC-HMS modeling software was used to develop runoff hydrographs from offsite drainage areas which were then added to the FLO-2D model as an inflow boundary condition. Models were created to identify the flooding risks on a conceptual level, to evaluate the final grading design, and to develop a stormwater permitting plan. Model results were also used to estimate the scour potential at the piles that supported the panels. This work demonstrates the use of spatially varied $2 \mathrm{D} H \& \mathrm{H}$ models in assessing potential sites and in designing stormwater control measures for solar farms.
\end{abstract}

\section{Background}

This paper describes the use of two-dimensional (2D) numerical hydrologic and hydraulic models to assess the impact of stormwater on proposed solar farm sites and to assess the design of a stormwater management system at a recently constructed solar farm. Where appropriate, 2D models are linked to an upstream watershed hydrologic and one dimensional (1D) hydraulic model.

\subsection{Solar Farms}

Solar farms (sometimes known as solar parks or solar fields) are the large scale application of solar photovoltaic (PV) panels to generate green, clean electricity at scale, usually to feed into the supply and distribution grid. Solar farms can cover between 1 acre and several hundred acres (from 0.4 ha to a few hundred hectares), and are usually developed in rural areas. Some may be located on completed landfills. Solar farms consist of arrays of ground mounted rectangular solar panels that are sloped to face the sun at either fixed or adjustable angles. Ancillary equipment includes access roads and electronic switching equipment.

\subsection{Stormwater Management Issues}

Solar panels are impervious. They are generally installed in a manner that allows stormwater to fall directly to the ground. In order to encourage infiltration and discourage erosion, the site is graded to encourage sheet flow of runoff across the site, including areas under the panels. Slopes are generally $<5 \%$ but may be as high as $10 \%$.

After panel installation, the ground is seeded with grass or other native cover. The grass is mowed once or twice a year.

Cook and McCuen (2013) analysed runoff from solar panel sites under pre- and post-development conditions with numerical models. They concluded that the panels themselves did not have a significant effect on runoff volumes, peak flows, or time to peak flow. However, these findings have not been verified by field measurements.

Barnard, Thomas E., Mohamed Agnaou and James Barbis. 2017. Two Dimensional Modeling to Simulate Stormwater Flows at Photovoltaic Solar Energy Sites. Journal of Water Management Modeling 25:C428. https://doi.org/10.14796/JWMM.C428 @ CHI 2017. www.chijournal.org ISSN 2292-6062. 
The approach generally taken in the design of stormwater management at solar farms is to consider the runoff characteristics of the soil to be identical to those of the soil in the absence of the panels. There may be an adjustment in the impervious area calculation to account for the presence of foundations, access roads and supporting structures. This impervious area is typically $<5 \%$ of the total site area.

\subsection{Regulatory Considerations}

A few states have developed guidance or specific requirements for stormwater management at solar farm sites. For example guidance from the Maryland Department of the Environment refers to the gas strip between panels as disconnections (see Figure 1). The disconnections should be located on gradual slopes $(\leq 5 \%)$ to maintain sheet flow. Level spreaders, terraces or berms may be used to maintain sheet flow conditions if the average slope is $>5 \%$ (MDE 2013).

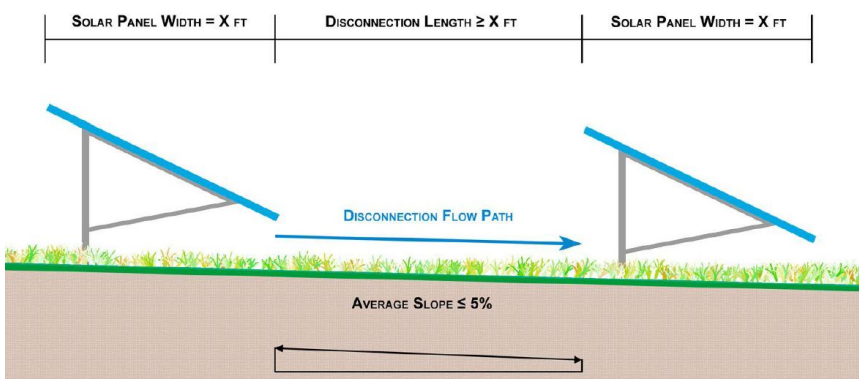

Figure 1 Typical installation for slope $\leq 5 \%$ (MDE 2013).

The Pennsylvania Department of Environmental Protection guidance includes (PA DEP 2011):

1. Vegetal cover has $90 \%$ or better uniform coverage since in a previous cover scenario, the vegetation will typically be the primary (and sometimes the sole) BMP:

- a meadow condition is preferable, particularly for slopes between $5 \%$ and $10 \%$;

- mowed areas, where approvable, should be kept to 4 in., $10.6 \mathrm{~cm}$ (min); and

- vegetated areas will not be subject to chemical fertilization or herbicides or pesticides.

2. Individual PV panels within an array are arranged in a fashion that:

- allows the passage of runoff between each module thereby minimizing the creation of concentrated runoff; and

- allows the growth of vegetation beneath and between arrays.

3. Ground mounted solar panels are supported with structures or foundations occupying minimal space (maximum $5 \%$ of the total project area).

4. Solar panels are situated on mild slopes (10\% maximum).
5. The lowest vertical clearance of the solar array is at an elevation of $10 \mathrm{ft}$ (3.05 $\mathrm{m}$ ) or less from the ground, but is also at an adequate height to promote vegetative growth below the array.

Under New Jersey law S-921 solar panels are now exempt from zoning limitations on impervious cover-a planning term for hard surfaces such as buildings and driveways that prevent water from absorbing into the ground (DeGrezia 2010). In regards to solar panels, municipalities had been inconsistent in their impervious cover requirements, with some treating solar panels as impervious. S-921 addresses this inconsistency_-solar panels cannot be restricted through impervious coverage limitations. Other agencies have similar exemptions.

\section{Stormwater Modeling for Solar Farms}

\subsection{D and 2D Modeling Approaches}

There two approaches to modeling stormwater flows at solar farm sites. The traditional approach (subcatchment 1D) is based on a network of subcatchments linked with 1D conveyance and flow control structures. In the 2D approach, a model domain is extended beyond the site boundary to include local runoff flowing onto the site. It is delineated into rectangular grid cells or triangular mesh nodes. The shallow water equations (Vreugdenhil 1994) are used to quantify flow between cells at each model time step. The two methods are compared in Table 1.

Table 1 Comparison of subcatchment $1 \mathrm{D}$ and $2 \mathrm{D}$ runoff methods.

\begin{tabular}{|c|c|c|}
\hline Component & Subcatchment 1D Approach & 2D Approach \\
\hline Precipitation & Time series & Time series \\
\hline Runoff & Various hydrologic methods & Mass balance \\
\hline Flow Paths & Predefined by user & $\begin{array}{l}\text { Model determines, may vary over } \\
\text { simulation }\end{array}$ \\
\hline Hydraulic Routing & $\begin{array}{l}\text { Sub catchment } \rightarrow 1 \mathrm{D} \text { conveyance } \\
\text { structure }\end{array}$ & Cell $\rightarrow$ Cell \\
\hline Input & $\begin{array}{l}\text { Geometery, travel time, } n \text {-value, } \\
\text { infiltration rates }\end{array}$ & $\begin{array}{l}\text { Elevation, } n \text {-value, infiltration rates, } \\
\text { boundary flows and water elevations }\end{array}$ \\
\hline Output & $\begin{array}{l}\text { Hydrograph, velocity and depth in } \\
\text { conveyance structures }\end{array}$ & $\begin{array}{l}\text { Hydrograph, velocity and depth time } \\
\text { series across entire site }\end{array}$ \\
\hline
\end{tabular}

Both approaches begin with a time series of precipitation. The rainfall event may vary or be constant with respect to space. The precipitation may represent a hypothetical design storm or an actual recorded event.

In the subcatchment 1D approach, the runoff rate from each subcatchment is calculated at each time step using any appropriate hydrologic method. For the 2D approach, the volume of runoff at each cell is calculated from a mass balance analysis of precipitation, net inflow, infiltration and the change in volume (depth $\times$ cell area).

The flow paths in the subcatchment 1D approach are pre-defined by the modeler. The discharge from any subcatchment is directed to another subcatchment, a 1D conveyance, or a flow control structure. 1D hydraulics are used to model flow 
through conveyance structures. The flow paths are constant throughout the simulation period. In the 2D approach water may flow between any two neighbouring cells in either direction over every time step. The rate of flow is determined from considerations of the hydraulic gradient, energy and momentum. This scheme allows flow to change direction, altering overall flow patterns during the simulation. At locations where the flow is one-dimensional in nature (flow paths are parallel), a 1D channel may be included within a 2D model.

The data required for subcatchment 1D models includes the delineation of subcatchments, travel time along each subcatchment's longest flow path and infiltration properties. For the 2D approach, the models require the elevation, ground surface roughness coefficients (Manning's $n$ values) and soil infiltration properties of each cell. Inflow hydrographs and initial surface water elevations at the boundaries may also be included.

The output from a subcatchment 1D model provides an outflow hydrograph from each subcatchment. The discharge, depth and velocity along the 1D conveyance segments are also generated. The 2D model will produce time series results for depth and velocity at all cells. Discharge hydrographs can be generated for any user defined cross section in the 2D model.

In general, 2D models are recommended for sites where the flow paths are unknown, two dimensional in nature or change during the storm event, or where information regarding the flow depths and velocities throughout the PV site are required.

\subsection{Linked Models}

Solar farm sites may be subject to runoff from upgradient sources. In such instances there are two options:

1. A single $2 \mathrm{D}$ model extended to the top of all catchments; and

2. Linked models that utilize a subcatchment 1D model for regional offsite runoff and a 2D model for the stormwater flows onsite and any local offsite runoff.

A single 2D model is simple in structure. When a site is near the top of a catchment, it is an appropriate option. However, if there is a large area contributing runoff to a site and the $2 \mathrm{D}$ regime is extended over the complete drainage area, the computation may require excessive time and computer power. Since the information of interest concerns the flows and velocities in the vicinity of the panels and the discharges from the site, it is not necessary to compute flows and velocities throughout the complete drainage area.

Figure 2 shows the configuration a site where the linked model option is appropriate. Subcatchments 1,2 and 3 discharge to the stream that flows near the edge of the panel array. High flows from this stream may encroach on the site. Subcatchment 4 flows directly on to the site.

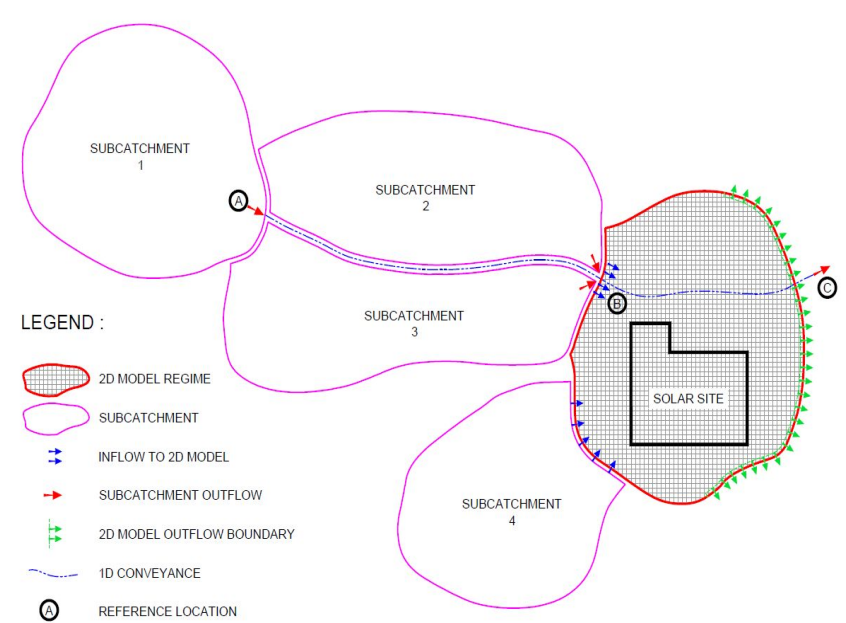

Figure 2 Schematic layout of linked model to simulate stormwater flow at solar site.

A subcatchment 1D model is constructed to simulate upgradient stormwater flows. Outflow hydrographs for subcatchments 1 through 4 are calculated using hydrologic methods. The subcatchment 1 hydrograph is routed from point $A$ to point $B$ using an appropriate routing procedure. At location $B$ the hydrographs for subcatchments 2 and 3 are added to discharge from stream A-B.

The 2D model domain is extended over the solar panels and includes the portion of the stream the flows near the site. Note that it includes the stream between locations B and C. The subcatchment 4 outflow is defined as an inflow boundary along the intersection of subcatchment 4 and the $2 D$ regime. At location $B$, the combined flows from subcatchments 2 and 3 and stream $A-B$ are defined as an inflow boundary. On the downslope edge of the $2 \mathrm{D}$ regime, an outflow boundary is defined.

\section{Case Studies}

\subsection{Preliminary Site Assessment}

Amec Foster Wheeler was tasked to evaluate potential flooding at three proposed solar farm sites in west Texas. The project sizes and flooding issues are shown in Table 2. All three sites had significant upstream catchments that were the sources of flows near the boundary and potentially onto the sites. The details of the analysis varied from site to site. This section describes the general modeling approach.

Table 2 Proposed sites in west Texas.

\begin{tabular}{ccc}
\hline Site & Size (ha) & Flooding lssues \\
\hline 1 & 1055 & $142 \mathrm{~km}^{2}$ upstream catchment, a draw along the site boundary \\
2 & 502 & Major river, controlled dam upstream, $1479 \mathrm{~km}^{2}$ additional catchment \\
3 & 1147 & $1786 \mathrm{~km}^{2}$ upstream catchment, private dam, diversions to irrigation canals \\
\hline
\end{tabular}

For each site a linked model set was developed. HECHMS software was used to produce hydrographs from regional 
upstream sources and to route the flow to the upstream boundary of the 2D domain. The FLO-2D software package was used to develop a 2D model extending over each site. A rectangular grid (typically $50 \mathrm{ft} \times 50 \mathrm{ft}, 15.24 \mathrm{~m} \times 15.24 \mathrm{~m}$ ) was defined. The domain of the model was expanded beyond the site boundary in order to include local upgradient flows that might impact the site. The HEC-HMS hydrographs were assigned as offsite inflows at appropriate locations along the boundary.

Figure 3 shows a typical configuration of the linked model set. The proposed site is indicated with the diagonal hatching. The 2D model regime is extended to the top of the local catchment. Flow from the regional catchment enters the $2 \mathrm{D}$ regime at two locations. DA-15 discharges into a branch of Leon Creek. The main stem of Leon Creek carries flow for DA-14 and other upstream subcatchments. Boundary cells located where the slope is away from the $2 \mathrm{D}$ regime are designated as outflow cells. The input parameters for the linked model are shown in Table 3.

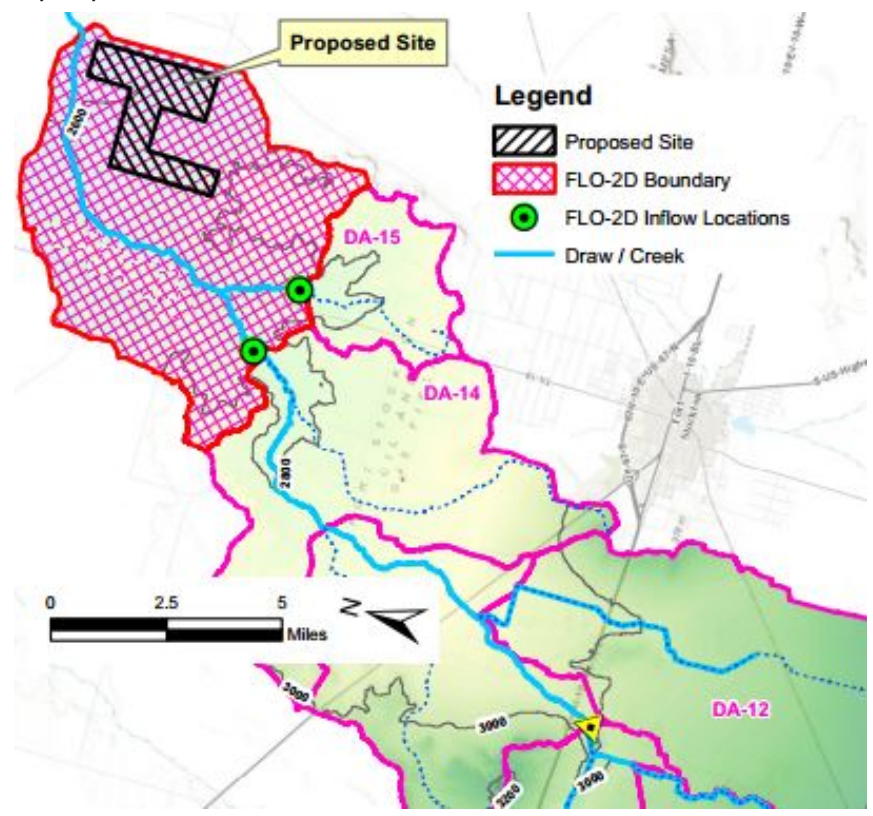

Figure 3 Layout of subcatchment 1D and 2D components for analysis of runoff.

Table 3 Input parameters for models.

\begin{tabular}{llll}
\hline & Subcatchment & 1D Routing & 2D \\
\hline Software & HEC-HMS & HEC-HMS & FLO-2D \\
Input Parameters & Precipitation & Channel Length & Preciptiation \\
& Time of Concentration & Channel Slope & Elevation \\
& Curve Number & Cross Section & $n$-value \\
& & & Curve Number \\
\hline
\end{tabular}

The sources of data are given in Table 4 . The $24 \mathrm{~h}$ precipitation values were obtained from Asquith and Roussel (2004). The $24 \mathrm{~h}$ precipitation depths for the west Texas sites are shown in Table 5. These total rain amounts were used with the SCS Type II curve to generate hyetographs for the model runs.
Table 4 Data sources for west Texas sites.

\begin{tabular}{lll}
\multicolumn{1}{c}{ Data } & \multicolumn{1}{c}{ Source } & \multicolumn{1}{c}{ Comments } \\
\hline Precipitation & Asquith and Roussel (2004) & Varied by site \\
Site elevation & Lidar & High quality \\
Vicinity elevation & USGS & $1 / 3$ arc second \\
Land use/land cover & National Land Cover Database & 2006 data, $30 \mathrm{~m} \times 30 \mathrm{~m}$ pixel size \\
Soils & USDA Web soil survey & Infiltration rates, particle size, depth to \\
& ESRI online & water table \\
Base maps & & \\
\hline
\end{tabular}

Table 5 Typical $24 \mathrm{~h}$ rainfall depths for west Texas sites.

\begin{tabular}{cc}
\hline Return Interval, $y$ & Total Depth, $\mathrm{mm}$ \\
\hline 5 & 76 \\
10 & 89 \\
25 & 102 \\
50 & 114 \\
100 & 152 \\
\hline
\end{tabular}

The topographic data that was used in the hydrologic analysis model, was developed by blending the following data sources using ESRI Spatial Analyst and 3D Analyst extensions:

- publicly available lidar data;

- USGS 1/3 arc second data for areas that are not covered by the lidar data; and

- supplemental field survey data for specific ground features (ditches, levees, ...) that are not captured by USGS DEM or lidar data.

The multiple topographic sources were blended together to achieve a surface that provides the appropriate level of hydrologic and hydraulic detail for a suitable grid spacing in the FLO-2D model. Ground surface elevations within the blended surface were in the NAVD88 vertical datum.

The USDA Web Soil Survey tool was used to query the Soil Survey Geographic Database (SSURGO), and to develop soil maps and reports for each project site. The tables were queried to obtain information on particle size, hydrologic soil group and infiltration rates.

Land cover data for each site was developed from the National Land Cover Database (Fry et al. 2011). This dataset is based on 16 land cover classifications and has a $30 \mathrm{~m} \times 30 \mathrm{~m}$ resolution.

The FLO-2D model for each site was developed according to the following procedure:

1. Elevations of the grid elements were assigned by building a point file from a DEM;

2. The curve numbers (CNs) used to calculate runoff were developed by combining the soil and the land cover data. The values were adjusted to Antecedent Runoff Condition I (ARC I) in consideration of the normally dry weather in the region; and

3. Manning's $n$ values were assigned according to the land cover following guidance in the FLO-2D reference manual as shown in Table 6. 
Table 6 Manning's $n$ values for land cover classifications.

\begin{tabular}{clc}
\hline NLCD ID & \multicolumn{1}{c}{ Description } & $n$ value \\
\hline 11 & Open Water & 0.018 \\
21 & Developed, Open Space & 0.040 \\
22 & Developed, Low Intensity & 0.068 \\
23 & Developed, Medium Intensity & 0.068 \\
31 & Barren Land & 0.011 \\
41 & Deciduous Forest & 0.360 \\
42 & Evergreen Forest & 0.320 \\
43 & Mixed Forest & 0.400 \\
52 & Shrub/Scrub & 0.100 \\
71 & Herbaceous & 0.368 \\
82 & Cultivated Crops & 0.170 \\
90 & Woody Wetlands & 0.086 \\
95 & Emergent Herbaceous Wetlands & 0.183 \\
\hline
\end{tabular}

\section{HEC-HMS Model}

The subcatchments were delineated using the DEM and ArcHydro tools

The lag time $t_{\text {lag }}$ for each subbasin, for use in the SCS unit hydrograph method, was computed according to the formula

$$
t_{\text {lag }}=0.6 t_{c}
$$

where the time of concentration, $t_{c^{\prime}}$ is given by

$$
t_{c}=t_{\text {sheet }}+t_{\text {shallow }}+t_{\text {channel }}
$$

Curve numbers were developed according to the same procedure used for the $2 \mathrm{D}$ cells.

\section{Hydraulic Routing}

Flow was routed through the 1D channels using the Muskingum-Cunge method. Channel lengths, slopes and cross sections were derived from the USGS elevation data. Routing parameters used for the natural (earthen) and irrigation (concrete) channel types are shown in Table 7.

Table 7 Routing parameters used for 1D conveyance structures.

\begin{tabular}{lcl}
\hline \multicolumn{1}{r}{ Channel Type } & Manning's $n$ & \multicolumn{1}{c}{ Cross Section Type } \\
\hline Natural & 0.055 & Eight point \\
Irrigation channel & 0.02 & Trapezoid \\
\hline
\end{tabular}

The HEC-HMS model was run for $5 \mathrm{~d}$. The outflow hydrographs were added to the FLO-2D model as inflow boundary conditions. The flows were spread across cells that represented channels. Figure 4 shows an example of inflow hydrographs. Note that the Node 1 hydrograph peaked at approximately 2500 $\mathrm{cfs}\left(71 \mathrm{~m}^{3} / \mathrm{s}\right)$ at $16 \mathrm{~h}$ into the simulation period while the Node 2 hydrograph peaked at $43500 \mathrm{cfs}\left(1203 \mathrm{~m}^{3} / \mathrm{s}\right)$ at $30 \mathrm{~h}$ after the start of the storm.

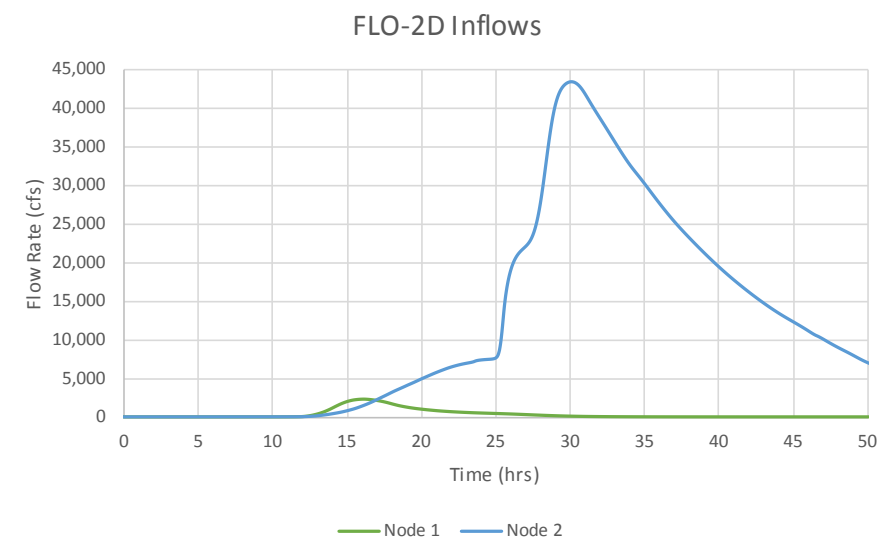

Figure 4 Inflow hydrographs at proposed solar site in west Texas.

The FLO-2D model was run for $48 \mathrm{~h}$. The software generated a time series of velocity and depth at each cell. This data was imported into ArcMap to produce maps of maximum depth and velocity such as those presented for site 3 in Figures 5 and 6 . For this site the figures indicate that flood depths were in the $0.5 \mathrm{ft}$ to $1.0 \mathrm{ft}(15.24 \mathrm{~cm}$ to $30.5 \mathrm{~cm})$ range in the small area in the northeast section of the site but remained $<0.5 \mathrm{ft}(15.24 \mathrm{~cm})$ throughout the remainder of the site. Maximum velocities were in the $0.5 \mathrm{ft} / \mathrm{s}$ to $1.0 \mathrm{ft} / \mathrm{s}(15.24 \mathrm{~cm} / \mathrm{s}$ to $30.5 \mathrm{~cm} / \mathrm{s}$ ) range in the western section of the site and a portion of the eastern section while remaining $<0.5 \mathrm{ft} / \mathrm{s}(15.24$ $\mathrm{cm} / \mathrm{s}$ ) throughout the remainder of the site. The flow in Leon Creek reached a depth of $8 \mathrm{ft}(2.44 \mathrm{~m})$ and a velocity $6 \mathrm{ft} / \mathrm{s}$ $(1.83 \mathrm{~m} / \mathrm{s})$ at a location along the centreline and northern end of the site. However, the Leon Creek flows did not encroach on the site.

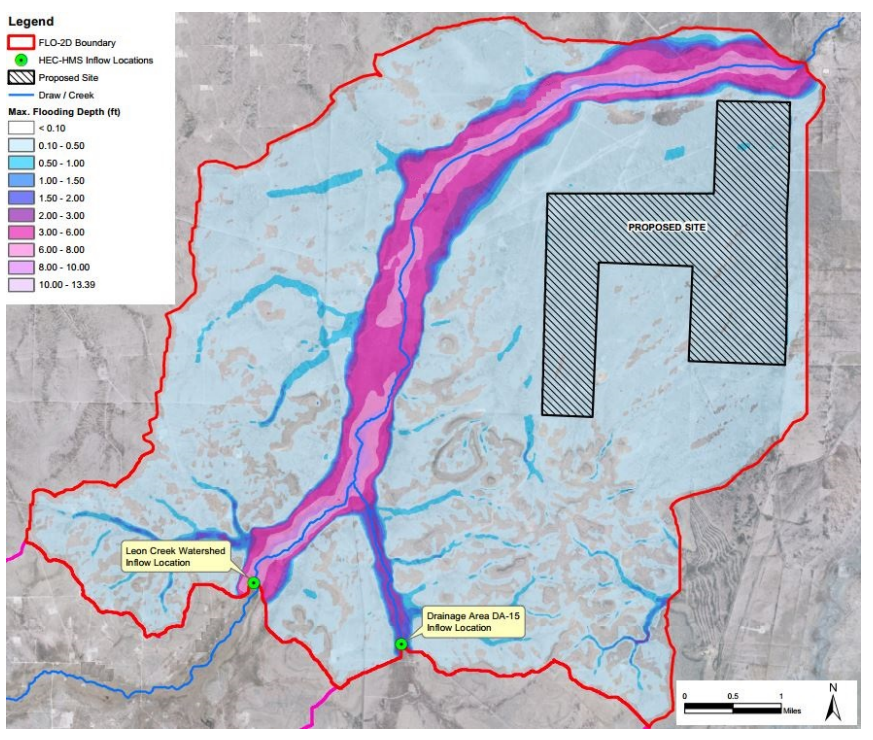

Figure 5 Maximum flow depths. 


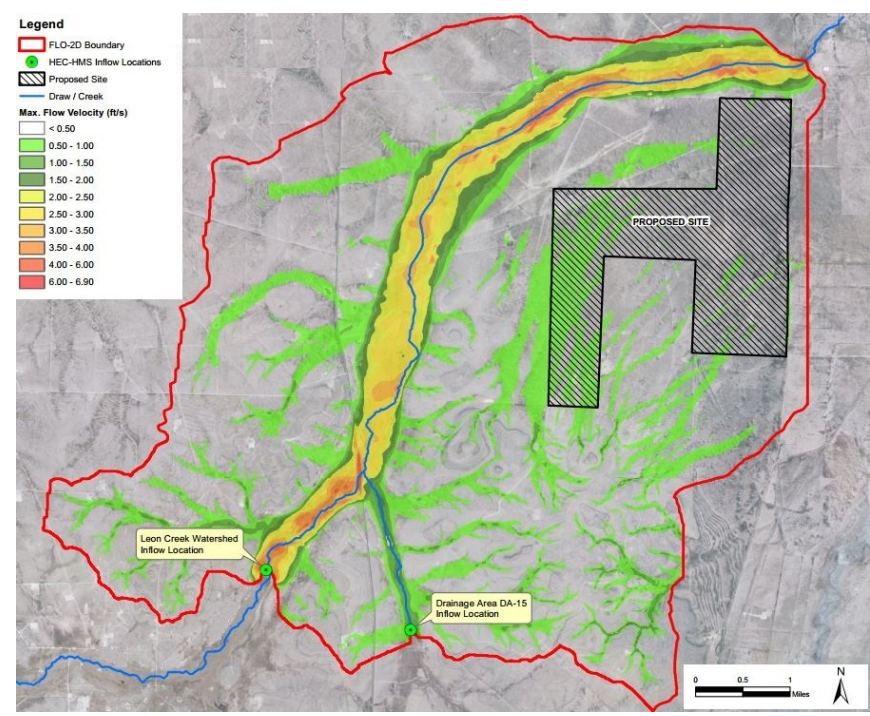

Figure 6 Maximum flow velocities.

\subsection{Design of Stormwater Controls}

Amec Foster Wheeler was tasked to develop a stormwater management plan for a proposed 1000 MW PV project at a 1060 acre (429 ha) site in Georgia (see Figure 7). The site straddles the topographic divide of three drainages. There is no flow of stormwater on to the site from offsite sources.

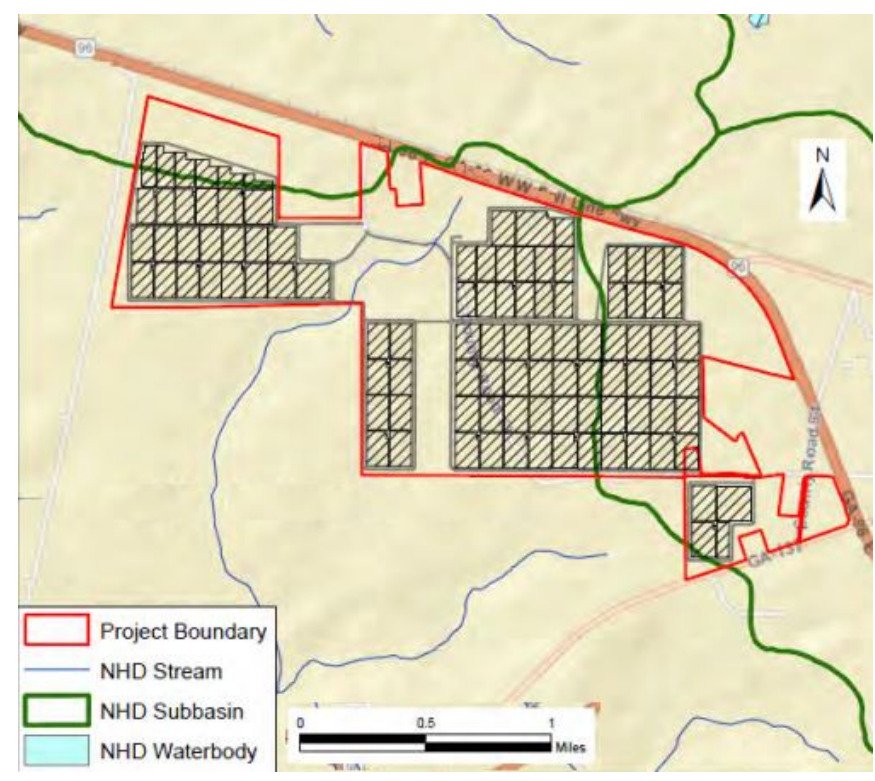

Figure 7 Site layout; hatching indicates the locations of solar panels.

Stormwater management was subject to the eleven minimum standards in the Georgia Stormwater Management Manual (Atlanta Regional Commission 2001). The focus of this analysis is to demonstrate that post development flows did not exceed pre-development flows for $24 \mathrm{~h}$ storms with $1 \mathrm{y}, 25 \mathrm{y}$ and $100 \mathrm{y}$ return intervals.
The site was graded by removing higher areas and constructing swales and detention ponds. Design criteria included:

- maximum depth for 100 y storm: $1 \mathrm{ft}(30.5 \mathrm{~cm})$;

- maximum slopes: south to north $2 \%$, east to west and north to south 5\%;

- material balance of cut and fill; and

- general maintenance of predevelopment flow paths.

The 2D model approach was selected for the project. FLO2D software was used to develop 133881 grid elements each $25 \mathrm{ft} \times 25 \mathrm{ft}(7.62 \mathrm{~m} \times 7.62 \mathrm{~m})$. The model domain included the site and was extended $\sim 300 \mathrm{ft}$ (91.4 m) beyond the property boundaries (Figure 8 below). Additional model features included a levee to represent the berming action of a highway located at the northern site boundary and seven culverts were included to simulate 1D flow within the 2D domain.

Elevations of the grid elements were developed from three data sources: field survey, photogrammetric survey and USGS 1/3 arc second DEM data. The $24 \mathrm{~h}$ rainfall depth was obtained from the Georgia Stormwater Management Manual (CSMM) (Atlanta Regional Commission 2001). The SCS Type II rainfall distribution was used to derive the hyetographs. Soil data was obtained from the U.S. Department of Agriculture web based soil survey and land use data were obtained from the 2011 U.S. Land Cover dataset. The curve numbers and Manning's $n$ values were assigned to grid cells based on land use using the ESRI ArcGIS Spatial Analyst tool. Initial abstraction was set to 0.05 .

In order to account for runoff leaving the site it was delineated into 13 subcatchment areas. Each area represents the catchment contributing to a discharge at the site boundary. The drainage area boundaries and the longest flow paths were determined using the ESRI ArcHydro tool. In the FLO-2D model, a cross section was defined where each subcatchment crossed the site boundary. This enabled FLO-2D to calculate a hydrograph for each subcatchment.

The final grading of the site was obtained by using an iterative process. Preliminary grading plans were produced and used to define the grid element elevations for the post development 2D model. The model was run and locations that did not meet the maximum depth and subcatchments that exceeded the no increase in runoff were identified. The grading was revised and in some cases berms and detention ponds were added. The peak runoff rate and total volume for each drainage area for pre and post-development conditions were compared. The process was repeated until the design criteria were met.

When the final grading was completed, results from the FLO-2D model were used to produce maps of maximum depth and velocity for each model run. Figures 8 and 9 present maps of maximum flood depth and velocity for the $100 \mathrm{y}$ storm. The dark red areas of Figure 8 indicate the locations of detention ponds. 


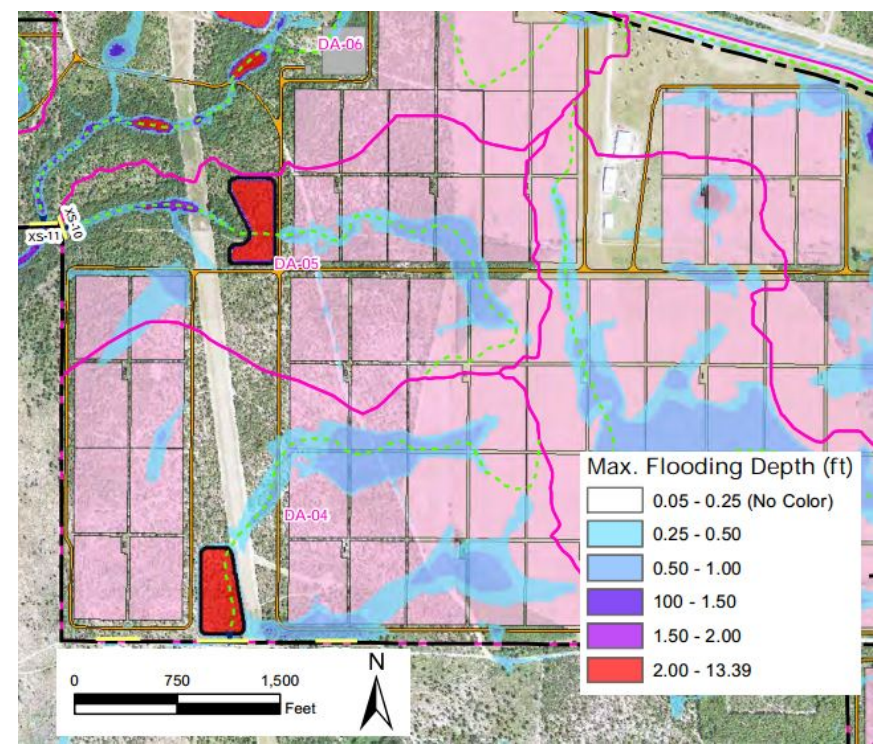

Figure 8 Maximum flood depths from $100 \mathrm{y}$ storm.

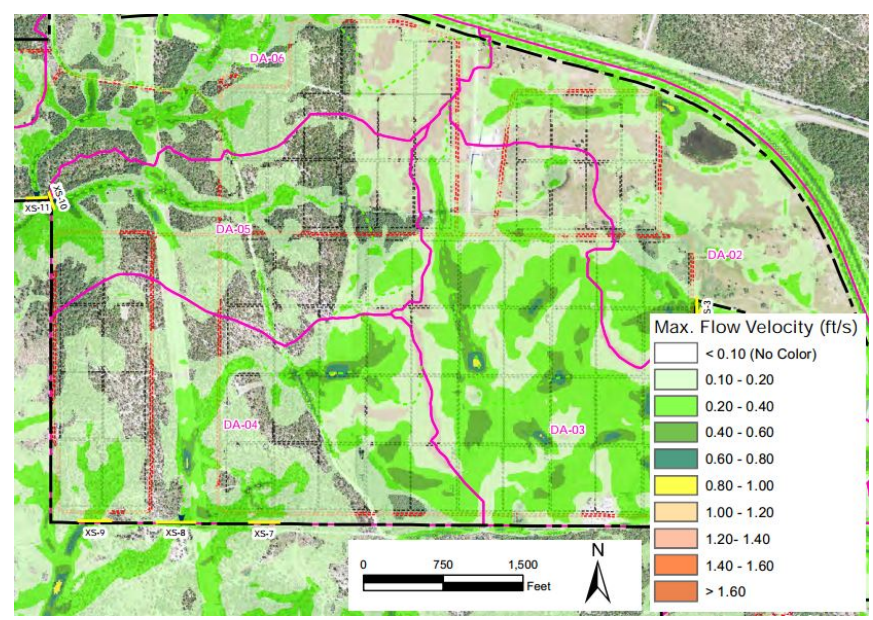

Figure 9 Maximum velocities for $100 \mathrm{y}$ storm.

The Georgia Stormwater Management Manual (Atlanta Regional Commission 2001) requires that all stormwater runoff generated from a site should be adequately treated before discharge. Site features are to be developed to capture and treat the water quality volume resulting from the first $1.2 \mathrm{in}$. (30.5 mm) rainfall from the site. The water quality volume is calculated by the following equation and Table 8 shows the calculated quantities for the project site.

$$
W Q_{v}=\frac{1.2 R_{v} A}{12}
$$

where:

$$
\begin{aligned}
W Q_{v}= & \text { water quality volume (acre-ft), } \\
A & =\text { drainage area (acre), and } \\
R_{v}=0.05 & +0.009(I)
\end{aligned}
$$

where:
$I=$ percent impervious cover (\%).

Table 8 Partial list water quality capture volume by drainage basin.

\begin{tabular}{lcccc}
\hline Basin & $\begin{array}{c}\text { Drainage Area } \\
\text { (ha) }\end{array}$ & $\begin{array}{c}\text { Impervious Area } \\
\text { (ha) }\end{array}$ & Percent Impervious & $W_{v}$ (ha-m) \\
\hline DA-01 & 27.3 & 0.80 & $2.97 \%$ & 0.064 \\
DA-02 & 72.8 & 0.36 & $0.49 \%$ & 0.12 \\
DA-03 & 93.2 & 1.06 & $1.14 \%$ & 0.17 \\
DA-04 & 65.4 & 0.00 & $0.00 \%$ & 0.10 \\
DA-05 & 52.5 & 0.00 & $0.00 \%$ & 0.08 \\
\hline
\end{tabular}

The potential for scour at the supporting driven piles was analysed using the methods described in Hydraulic Engineering Circular 18 (Arneson et al. 2012). The maximum depth and velocities occurring during the $100 \mathrm{y}$ storm event were considered. The foundation piles at the site consisted of standard structural steel wide flange shapes. In the HEC-18 calculation the parameters for a square nose section were used. The angle of attack was varied from $0^{\circ}$ to $90^{\circ}$. The angle of attack used was $45^{\circ}$ as it resulted in the greatest scour depth. The calculated scour depth ranged from $0.6 \mathrm{ft}$ to $0.7 \mathrm{ft}(18.3 \mathrm{~cm}$ to $21.3 \mathrm{~cm})$. This value represents the worst case for the site. The scour depth will be lower over the majority of the site. Figure 10 shows how scour depth varies over the range of depths and velocities predicted to occur at the site for the 100 y storm.

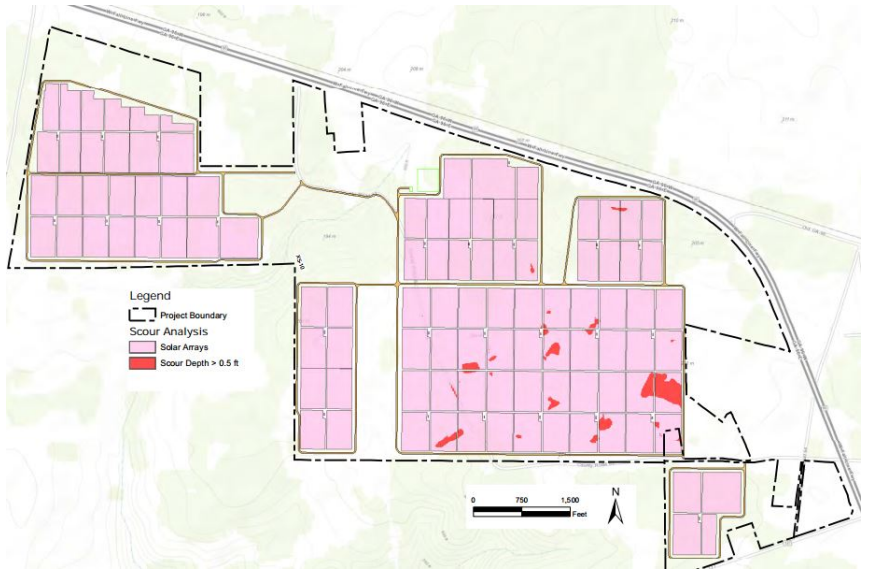

Figure 10 Scour analysis at solar farm site.

\section{Conclusions}

This paper presents procedures modeling the runoff from PV sites under pre- and post-development conditions. The traditional subcatchment 1D approach is compared with the 2D approach. In general, 2D models are recommended for sites where the flow paths are unknown, are two-dimensional in nature or change during the storm event, or where information regarding the flow depths and velocities throughout the PV site is required. 2D models produce information regarding flow depths and velocities that is not available from subcatchment runoff models.

For sites that are subject to runoff originating from large upgradient areas a linked model set is recommended. Such a 
configuration is computationally efficient and produces the results required for the design of the facility.

\section{References}

Arneson, L. A, L. W. Zevenbergen, P. F. Lagasse and P.E. Clopper. 2012. Evaluating Scour at Bridges, 5th ed. Washington, DC: U.S. Department of Transportation Federal Highway Administration. Hydraulic Engineering Circular No. 18. https://www.fhwa.dot.gov/engineering/hydraulics/pubs/ hif12003.pdf

Asquith, W. H. and M. C. Roussel. 2004. Atlas of Depth-Duration of Precipitation Annual Maxima for Texas. Austin, TX: U.S. Geological Survey Water Resources Division. FHWA/TX-04/51301-01-1. https://pubs.usgs.gov/sir/2004/5041/pdf/sir2004-5041.pdf

Atlanta Regional Commission. 2001. Georgia Stormwater Management Manual. Vol 2: Technical Handbook. Atlanta, GA.: Atlanta Regional Commission. http://documents.atlantaregional.com/gastormwater/ GSMMVol2.pdf

Cook, L. M. and R. H. McCuen. 2013. “Hydrologic Response of Solar Farms." Journal of Hydrologic Engineering 18:536-41. https://doi.org/10.1061/(ASCE)HE.1943-5584.0000530.
DeGrezia, C. 2010“New Legislation Promotes Solar Panel Development." New Jersey Zoning and Land Use Law. www.njlandlaw.com/archives/815\#more-815

FLO-2D. 2015. FLO-2D Reference Manuals. Nutrioso, AZ: FLO-2D Software. https://www.flo-2d.com/download/

Fry, J., G. Xian, S. Jin, J. Dewitz, C. Homer, L. Yang, C. Barnes, N. Herold and J. Wickham. 2011. “Completion of the $2006 \mathrm{Na}$ tional Land Cover Database for the Conterminous United States." Photogrammetric Engineering and Remote Sensing 77 (9): 858-64.

MDE (Maryland Department of the Environment). 2013. Stormwater Design Guidance-Solar Panel Installation. Baltimore, MD: Maryland Department of the Environment. http://mde.maryland.gov/programs/water/StormwaterManagementProgram/Documents/ESDMEP\%20Design\%20Guidance\%20Solar\%20Panels.pdf

PA DEP. 2011 Information to Use in the Determination of Stormwater Management (SWM) Impacts for Solar Projects. http://www.chesco.org/DocumentCenter/View/7375

Vreugdenhil, C. B. 1994. Numerical Methods for Shallow Water Flow. Boston, MA: Kluwer Academic Publishers. 